\title{
Islet Cell Surface Antibodies from Insulin-dependent Diabetics Bind Specifically to Pancreatic B Cells
}

\author{
M. Van De Winkel, G. Smets, W. Gepts, and D. Pipeleers, Department of \\ Metabolism and Endocrinology, Department of Pathology, Fakulteit \\ Geneeskunde en Farmacie, Vrije Universiteit Brussel, 1090 Brussels, Belgium
}

A в S T R A C T Viable rat islet cells were used to detect islet cell surface antibodies (ICSA) in the sera of diabetic and control patients. ICSA were present in almost all recent-onset insulin-dependent diabetics younger than $30 \mathrm{yr}(15 / 16)$; their incidence in other diabetics $(6 / 22)$ was also higher than in normal controls $(1 / 18)$ or in patients with autoimmune thyroiditis $(1 / 12)$. The varying specificity of the ICSA for the different islet cell types led to the recognition of class I sera, whose ICSA bind exclusively to B cells, class II sera, binding only to A and pancreatic polypeptide (PP) cells and class III sera, reacting with the three islet cell types but not with $\mathrm{D}$ cells. Most recent-onset insulin-dependent diabetics younger than 30 contained class I-ICSA, which is consistent with an autoimmune basis of their disease and with an involvement of surface antibodies in the B cell destruction. The presence of class II ICSA in three older diabetics and in one normal control raises the question whether autoimmune reactions against $\mathrm{A}$ and PP cells exist and are associated with a distinct entity in islet disease.

It is concluded that the autoimmune form of diabetes mellitus represents a heterogeneous group, in which ICSA-positive patients can be distinguished on the basis of their ICSA-binding to one or more islet cell types.

Three techniques can be used for the further identification of circulating ICSA, namely binding experiments with purified A or B cells, electron microscopical analysis of ICSA-binding islet cells purified by fluorescence-activated cell sorting, and the immunocytochemical characterization of ICSA-positive cells.

\section{INTRODUCTION}

The concept that autoimmunity is involved in the pathogenesis of insulin-dependent diabetes mellitus

Part of this work has been presented at the 17th Annual Meeting of the European Association for the Study of Diabetes, Amsterdam 1981. Diabetologia. 21: (Abstr. 536).

Address reprint requests to Dr. Pipeleers.

Received for publication 19 November 1981 and in revised form 23 February 1982. $(\text { IDDM })^{1}$ was first suggested by the lymphocytic infiltration of the islets of recently diagnosed insulin dependent diabetics (1) and was later documented by the description of cellular and humoral autoimmune processes at the onset of the insulin dependency (2-8).

It has often been proposed that the immune reactivity to pancreatic islet cells is directly responsible for the massive B cell destruction in IDDM; this hypothesis was recently supported by the in vitro observation that lymphocytes as well as circulating antibodies from IDDM inhibit glucose-induced insulin release and damage mammalian islet cells (9-11). To further test the eventual diabetogenic role of circulating islet cell surface antibodies (ICSA), we have examined whether they bind specifically to pancreatic B cells, which would represent another argument in favor of their diabetogenic action in vivo. This study consisted in binding experiments with purified A or B cells, and in the electron microscopical and immunocytochemical identification of the ICSA-binding islet cells.

\section{METHODS}

Preparation of ICSA. Sera were obtained from 18 normal controls, 24 IDDM, 11 noninsulin-dependent diabetics, 3 cases of secondary diabetes after chronic pancreatitis, and 12 patients with autoimmune thyroiditis (age $>40 \mathrm{yr}$ ) presenting circulating antibodies against thyroglobulin and thyroid microsomes.

IDDM were defined on the basis of their susceptibility to ketosis and were examined within $1 \mathrm{wk}$ after diagnosis; all noninsulin-dependent diabetics presented a fasting hyperglycemia and glucosuria at the time of diagnosis and were studied within $5 \mathrm{yr}$ after diagnosis. The sera were stored at $-20^{\circ} \mathrm{C}$ until heat inactivation $\left(56^{\circ} \mathrm{C}, 20 \mathrm{~min}\right)$ and ammonium sulphate precipitation (first at $50 \%$ saturation, then at $33 \%)$; the precipitated immunoglobulins were dissolved in phosphate-buffered saline (PBS, pH 7.4), then dialyzed against the same buffer for $36 \mathrm{~h}$ at $4^{\circ} \mathrm{C}$, and finally frozen in $100-\mu \mathrm{l}$ aliquots. Before use, the antibodies were centri-

\footnotetext{
'Abbreviations used in this paper: ICA, circulating islet cell antibodies; ICSA, islet cell surface antibodies; IDDM, insulin-dependent diabetes mellitus; KRH noCa, Hepesbuffered Krebs-Ringer medium without calcium; NIDDM, noninsulin-dependent diabetes mellitus; PBS, phosphatebuffered saline; PP, pancreatic polypeptide.
} 
fuged at $100,000 \mathrm{~g}$ for $30 \mathrm{~min}$ in a Beckman Airfuge (Beckman Instruments, Inc., Fullerton, CA).

Membrane fluorescence of islet cells. Islet cell suspensions and purified A or B cells were prepared from adult male Sprague-Dawley rats as described previously (12); the purified B cell population consisted of $95 \% \mathrm{~B}$ cells and the purified A cell fraction of $80 \%$ A-cells. After a 20 -min preincubation in CMRL-1066 (Gibco Laboratories, Glasgow, Scotland) at $37^{\circ} \mathrm{C}$ under $5 \% \mathrm{CO}_{2}$, the cells were washed in Hepesbuffered Krebs-Ringer medium without calcium (KRH noCa [12]), supplemented with $0.02 \mathrm{~g} / 100 \mathrm{ml}$ sodium azide and $1 \mathrm{~g} / 100 \mathrm{ml}$ bovine serum albumin (BSA, fraction V, Sigma Chemical Co., St. Louis' MO); (4-2-hydroxy ethyl) piperazine-1 ethane-sulphonic acid (Hepes) was purchased from Merck AG (Darmstadt, West Germany). Samples of $10^{5}$ cells, suspended in $100 \mu \mathrm{l} \mathrm{KRH}$ noCa, were incubated with 100 $\mu l$ antibodies (final dilution $1: 2$ as compared with unextracted serum) at $4^{\circ} \mathrm{C}$ for $2 \mathrm{~h}$ under constant shaking and ambient atmosphere. After washing the cells twice in KRH noCa, the cell pellet $(150 \mathrm{~g}, 10 \mathrm{~min})$ was resuspended in 400 $\mu \mathrm{l} \mathrm{KRH} \mathrm{noCa}$, and incubated for another $30 \mathrm{~min}$ at $4^{\circ} \mathrm{C}$ with rhodamine-labeled anti-human immunoglobulins; tetra methyl rhodamine isothiocyanate conjugated goat anti-Fc human IgG (GAHu-IgG/Fc-TRITC) was purchased from Nordic Laboratories (Tilburg, The Netherlands) and used at final dilution 1:20. The cells were then extensively washed in KRH noCa, resuspended, and analyzed with a Leitz Dialux 20 EB, equipped with Ploemopak N2-1 (E. Leitz, Wetzlar, West Germany). Each serum was tested on at least two different islet cell preparations; for each serum, two investigators, having no knowledge of its origin, examined 400600 cells for the presence of a fluorescent ring reaction that, at a higher magnification, corresponded with multiple fluorescent spots uniformly distributed over the cell surface. Within each experiment, two standard sera were included, one reacting with $>80 \%$ of the islet cells, the other with exclusively $B$ cells; the interassay variation in the percent positive cells for each of these sera was $15 \%$. When the percent positive cells obtained by the two observers for the same microscope slides were compared, no statistically significant difference was noted between their results (paired $t, P<0.01$ ). All results were expressed as the mean of the percent positive cells noted on three or four slides by the two investigators. B cell-specific sera were also examined after three successive absorptions with blood, islet, or spleen cells, or with acetone extracted liver of pancreatic tissue (8).

Sorting of ICSA-positive cells. ICSA-positive cells were separated from ICSA-negative cells by fluorescence-activated cell sorting (13), using a FACS IV (Becton-Dickinson Co., Sunnyvale, CA). The fluorescence emitted by rhodamine-labeled cells was selected as sorting parameter; a 17101 Krypton laser (520 nm-120 mW; Spectra-Physics, Inc., Mountain View, CA) was used for excitation and an LP 580 filter (Ditric Optics, Inc., Marlboro, MA) for emission detection; PMT voltage was $750 \mathrm{~V}$ and the conversion gain of the fluorescence $8 \times 0.5$. Sorting was carried out in $K R H$ noCa at $17^{\circ} \mathrm{C}$. The cell separation was evaluated by comparing visually the membrane fluorescence of the sorted positive and negative cells. Sorted cells were also processed for electron microscopy, fixing them at $20^{\circ} \mathrm{C}$ in $4.5 \%$ (vol/ vol) glutaraldehyde (0.1 mol/liter phosphate buffer, $\mathrm{pH} 7.4)$ and postfixing in $1 \%$ (wt/vol) $\mathrm{OsO}_{4}$; after staining the cells with $5 \%$ (wt/vol) uranylacetate, they were pelleted in an Eppendorf microfuge tube and covered with $10 \mu \mathrm{l}$ fibrinogen $(1 \% \mathrm{wt} / \mathrm{vol})$ and $2 \mu \mathrm{l}$ thrombin $(2,000 \mathrm{IU} / \mathrm{ml})$; just before complete coagulation, most of the supernatant was removed and the cells, covered with an ultrathin fibrin layer, were dehydrated in successively $25,50,75,90$, and $100 \%$ (vol/vol) ethanol and $100 \%$ (vol/vol) propylene oxide, before embedding in araldite. Ultrathin sections were stained with lead citrate $(0.26 \% \mathrm{wt} / \mathrm{vol})$ and analyzed with a Zeiss EM 9S electron microscope (Carl Zeiss, Inc., Oberkochen, West Germany).

Immunocytochemistry for pancreatic hormones. Islet cells, incubated with human antibodies and rhodamine labeled anti-human immunoglobulins, were first washed with $\mathrm{KRH}$ noCa and then with PBS supplemented with $0.02 \mathrm{~g} /$ $100 \mathrm{ml} \mathrm{NaN}$. After fixation in $2 \%$ formaldehyde (30 min, $4^{\circ} \mathrm{C}$ ), the cells were extensively washed in PBS and the final pellet resuspended in $20 \mu \mathrm{l}$ distilled water containing $0.5 \mathrm{~g} /$ $100 \mathrm{ml}$ bovine serum albumin and dried on a microscope slide. The dried cells were treated with $50 \%$ ethanol ( $15 \mathrm{~min}$, $-20^{\circ} \mathrm{C}$ ), again washed extensively with PBS and then incubated for 30 min with guinea pig or rabbit antipancreatic hormone antibodies; after three washes with PBS, the cells were finally incubated with the corresponding fluorescein labeled second antibodies ( $30 \mathrm{~min})$, again washed with PBS-, mounted and analyzed by fluorescence microscopy. For each condition, 100-200 ICSA-positive cells were examined for a positive reaction with antibodies to insulin, glucagon, somatostatin, or pancreatic polypeptide.

Guinea pig antiinsulin serum (final dilution 1:200) was a gift from Dr. P. H. Wright (when at Indiana University, Indianapolis, IN), rabbit antiglucagon serum (final dilution 1:200) from Dr. F. H. Bosman (Rijksuniversiteit Leiden, The Netherlands), rabbit antisomatostatin (final dilution 1:100) from Dr. J. De Mey (when at the Vrije Universiteit Brussel), and rabbit antipancreatic polypeptide (final dilution 1:200) from Dr. R. Chance (Eli Lilly Research, Indianapolis). Fluorescein isothiocyanate-conjugated anti-guinea pig immunoglobulins were purchased from Nordic Laboratories.

\section{RESULTS}

Islet cell binding to circulating surface antibodies. Rhodamine-labeled anti-human immunoglobulins were used to visualize binding between dissociated rat islet cells and human $\gamma$-globulins prepared from diabetic and control sera. At final antibody concentrations of $1: 2$, no fluorescent rings were observed with $17 / 18$ normal control sera nor with $11 / 12$ patients with autoimmune thyroiditis; in contrast, the $\boldsymbol{\gamma}$-globulins from one control, one patient with autoimmune thyroiditis and 21/38 diabetics yielded fluorescent rings in 30$90 \%$ of the islet cells and were therefore considered as ICSA-positive. These data vary from those of Lermark et al. (8) who, at similar dilutions, detected in average $8 \%$ positive cells in normal controls and $38 \%$ in the ICSA-positive sera. Since dilution of the sera decreased the intensity of the cellular fluorescence, the effect of a further fourfold dilution of the antibodies upon the percent positive cells was determined for five sera that yielded an intense fluorescent ring in concentrated $(1: 2)$ conditions. Since no statistically significant difference was noted between the percent positive cells at the two tested antibody concentrations, it is unlikely that differences in antibody titer are responsible for the varying percent positive cells that were observed with various sera.

When the occurrence of ICSA was correlated with the type of diabetes (14), they appeared most fre- 
TABLE I

Occurrence of Circulating Islet Cell Surface Antibodies

\begin{tabular}{lrr}
\hline & $n$ & ICSA+ \\
\hline Controls & 18 & 1 \\
Diabetic patients & 38 & 21 \\
Recent onset IDDM $<30 \mathrm{yr}$ & 16 & 15 \\
& 8 & 1 \\
NIDDM $>30 \mathrm{yr}$ & 11 & 5 \\
Secondary diabetes & 3 & 0 \\
Patients with autoimmune & & \\
$\quad$ thyroiditis & 12 & 1 \\
\hline
\end{tabular}

quently in recent-onset IDDM (16/24); ICSA were also detected in 5/11 noninsulin-dependent diabetics (NIDDM) but were absent in three cases of secondary diabetes after chronic pancreatitis. The incidence of ICSA was particularly high $(15 / 16)$ in the insulin-dependent diabetics younger than $30 \mathrm{yr}$, whereas the older age group contained only one positive serum on eight cases (Table I).

When the specificity of the antibody binding to islet cells was tested, no absorption was observed with spleen or blood cells, nor with an acetone powder of liver; on the contrary, both pancreatic and islet tissue removed all ICSA. Islet cells that were kept for $16 \mathrm{~h}$ in tissue culture (CMRL-1066-5\% $\mathrm{CO}_{2}$ ), yielded in general a higher fluorescence intensity per positive cell than those used immediately after dissociation; such preincubation did, however, not increase the percent positive cells, and neither did a dissociation procedure without trypsin.

Heterogeneity in ICSA. The intensity of the fluorescent ring reaction differed for the various sera tested, indicating differences in titer and/or affinity of the diabetic ICSA. At final dilutions of 1:20 for example, the fluorescent rings were still detected with $5 / 15$ recent-onset IDDM, but not in the other sera.
The percent positive islet cells varied also from 30 $90 \%$ for the different sera tested. It was however noted that certain sera bound exclusively to the larger islet cells, whereas others reacted only with the smaller cells (Fig. 1). As the size of the insulin-containing B cells is significantly larger than that of the other islet cells (12), further studies were undertaken to examine specific binding of ICSA with certain islet cell types.

Characterization of ICSA-binding cells. To detect ICSA, directed against a specific islet cell type, islet cell populations, purified in either B-cells $(>95 \% \mathrm{~B})$ or non-B cells ( $80 \%$ A, $10 \%$ D, 5\% PP), were incubated in parallel with the various ICSA-positive sera (Table II).

In the recent-onset IDDM younger than $30 \mathrm{yr}$ $13 / 15$ samples with ICSA reacted only with the B cell population, in which $60-90 \%$ of the cells were rhodamine positive. In the remaining two cases, an equally strong reaction was observed with $B$ and with non-B cells, as was also the case in the one ICSA-positive patient with autoimmune thyroiditis. The ICSA identified in the one IDDM older than $30 \mathrm{yr}$ did not bind to $B$ cells, but reacted with $75-85 \%$ of the non$B$ cells; this was also observed with the one ICSA-positive control.

In the group of NIDDM, 2/5 ICSA-positive sera reacted exclusively with non- $B$ cells. In the other three cases, a selective binding to $B$ cells was indicated by a weak fluorescent ring reaction that corresponded, at higher magnification, with multiple fluorescent dots on the cell periphery.

On the basis of these observations, the ICSA-positive sera were subdivided in class I (B cell specific), class II (non-B cell specific), and class III (binding to B and non-B cells) (Table II).

This heterogeneity in specificity for different islet cell types was also evident from electron micrographs of the ICSA-positive cells. In these experiments, dissociated islet cells were incubated with sera from class

TABLE II

Binding of ICSA to Rat Islet Cells

\begin{tabular}{|c|c|c|c|c|}
\hline \multirow[b]{2}{*}{ Distribution of ICSA+ sera } & \multirow[b]{2}{*}{ ICSA } & \multicolumn{3}{|c|}{ Islet cell preparations } \\
\hline & & $\begin{array}{l}\text { Dissociated } \\
\text { islet cells }\end{array}$ & $\begin{array}{l}\text { Purified } \\
\text { A cells }\end{array}$ & $\begin{array}{l}\text { Purified } \\
\text { B cells }\end{array}$ \\
\hline & & \multicolumn{3}{|c|}{$\%$ positive cells } \\
\hline $\begin{array}{l}\text { 13/15 IDDM }<30 \mathrm{yr} \\
3 / 5 \text { NIDDM }\end{array}$ & Class I & $50-60$ & $<5$ & $60-90$ \\
\hline $\begin{array}{ll}1 / 1 & \text { IDDM > 30 yr } \\
2 / 5 & \text { NIDDM } \\
1 / 1 & \text { Control }\end{array}$ & Class II & $30-40$ & $75-85$ & $<5$ \\
\hline $\begin{array}{l}2 / 15 \text { IDDM }<30 \mathrm{yr} \\
1 / 1 \text { Thyroiditis }\end{array}$ & Class III & $80-90$ & $75-85$ & 75-95 \\
\hline
\end{tabular}



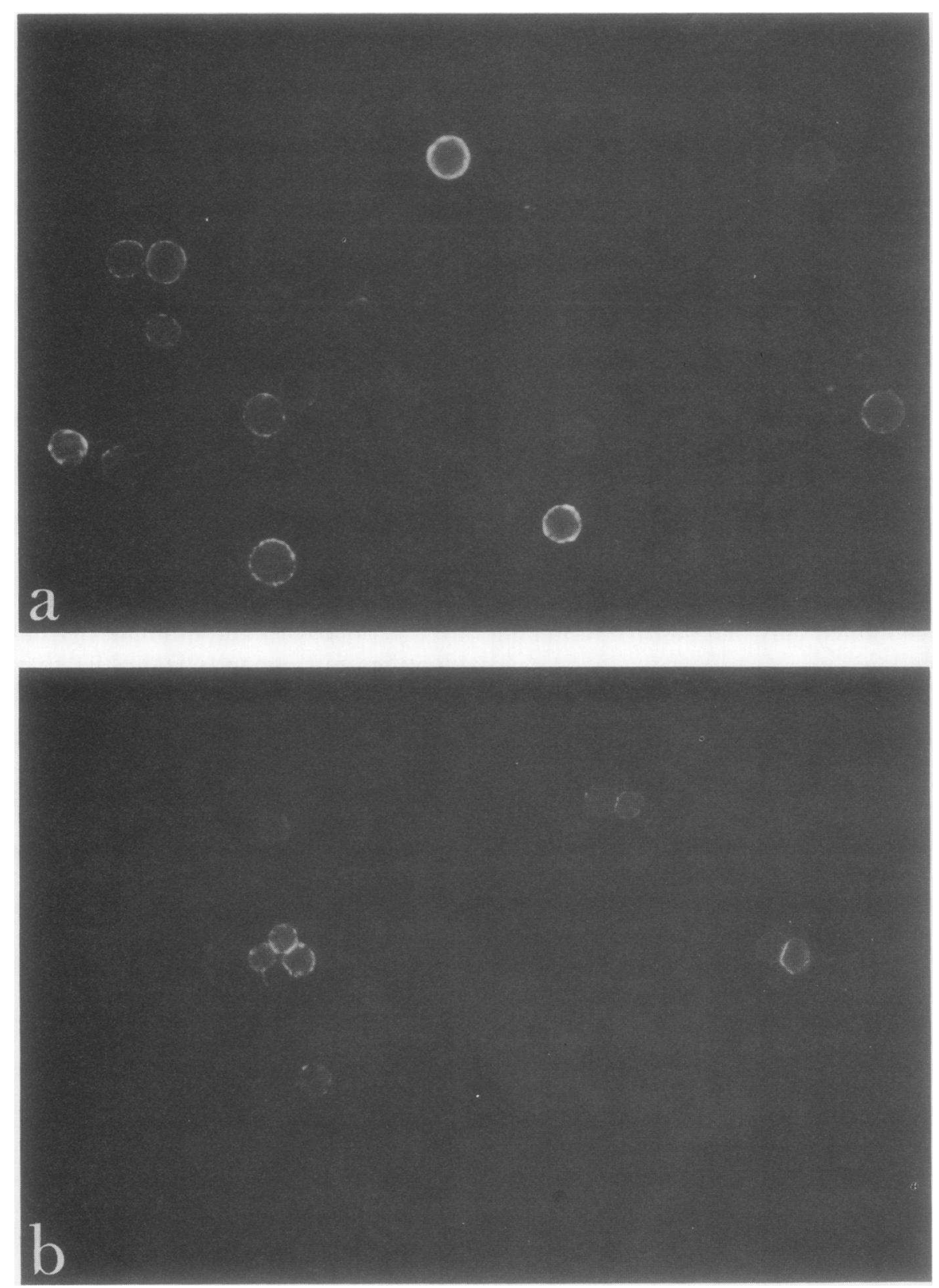

Figure 1 Binding of ICSA to unpurified islet cells. After incubation the cells with class I sera and with rhodamine-labeled anti-human antibodies, a fluorescent ring reaction was noted on the larger cells (a); the use of class II sera resulted in a positive reaction with the smaller islet cells (b). (X200).

I or II, then exposed to rhodamine-labeled anti-human antibodies and finally sorted on the basis of rhodamine fluorescence. After appropriate window setting, the fluorescence-activated cell sorter separated the rhodamine positive cells from the negative ones (Fig. 2) and resulted in the purification of the ICSA-positive cells. When the ICSA-positive cells were examined electron microscopically, $>95 \%$ of the cells corre- sponded to B cells for class I sera (Fig. 3a); islet cells binding to class II sera consisted on the other hand for $80 \%$ of A cells (Fig. $3 \mathrm{~b}$ ).

The ICSA-positive cells were also identified through immunocytochemical characterization of their cytoplasmic hormone. ICSA-positive cells, recognized by their rhodamine-positive ring, were therefore exposed to immunofluorescent reactions for pancreatic hor- 

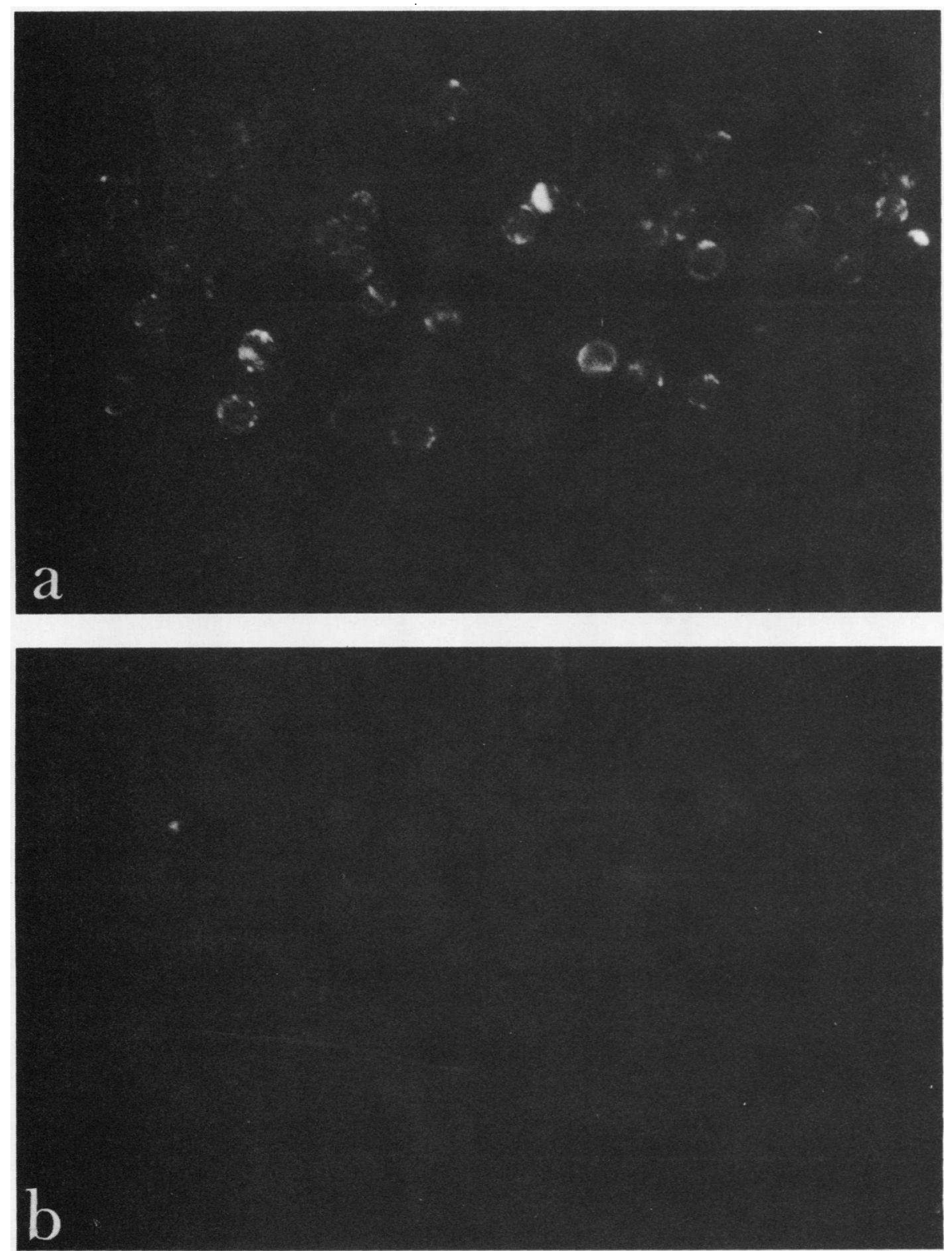

Figure 2 Purification of ICSA-bound islet cells by fluorescence-activated cell sorting. One of the sorted fractions is composed of rhodamine-labeled islet cells (a), whereas almost no cellular fluorescence was noted in the other cell fraction (b). (×200).

mones and examined for the presence of a fluoresceinpositive cytoplasm. These double-label experiments indicated that the ICSA from class I bound to insulincontaining cells and not to glucagon-containing cells (Fig. 4). Class II ICSA reacted on the other hand with cells staining positively for glucagon or pancreatic polypeptide, but not for insulin or somatostatin (Fig. 4); it thus turned out that for class II sera $80-90 \%$ of the ICSA-positive cells were glucagon-containing cells and $10-20 \%$ pancreatic polypeptide (PP)-containing cells. Identical results were obtained by double label experiments on the sorted ICSA-positive cell fractions.

\section{DISCUSSION}

Circulating islet cell antibodies (ICA) have been first defined on the basis of a positive immunofluorescent reaction with islet cell cytoplasm in frozen pancreatic sections (3). A large scale application of this technique led to the detection of a high incidence of ICA in 

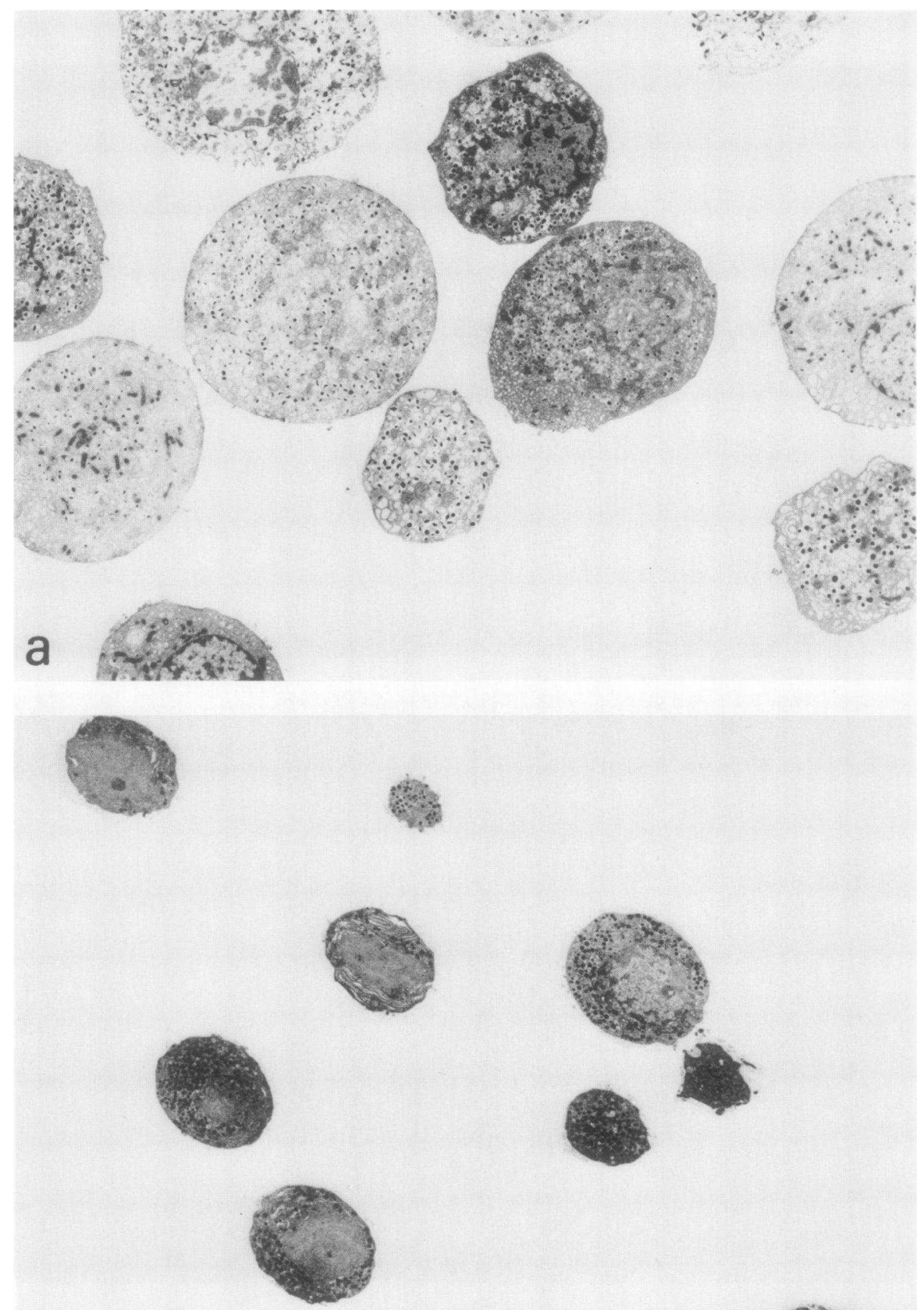

b

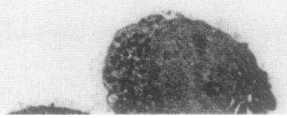

Ficure 3 Electron microscopy of ICSA-binding islet cells. The cells that were sorted after incubation with class I sera, corresponded to B-cells (a); sorting after exposure to class II sera yielded a cell population that was mainly composed of A-cells (b). $(\times 1,800)$.

FIGURE 4 Immunocytochemical characterization of ICSA-bound islet cells. Unpurified islet cells were simultaneously examined for their membrane binding to ICSA visualized by a rhodamine-positive ring in the left panel, and their cytoplasmic binding to pancreatic hormone antibodies, shown by a fluorescein-positive cytoplasm in the right panel; the nuclei remained negative. When incubated with class I sera, the ICSA positive cells $\left(a_{1}, a_{2}\right)$ were found to correspond to insulin containing islet cells (b) but not to glucagon containing cells (c). Exposure to class II sera, yielded ICSA-positive cells $\left(d_{1} d_{2}\right)$ that contained either glucagon (e) or pancreatic polypeptide (f), but no insulin or somatostatin. $(\times 320)$. 

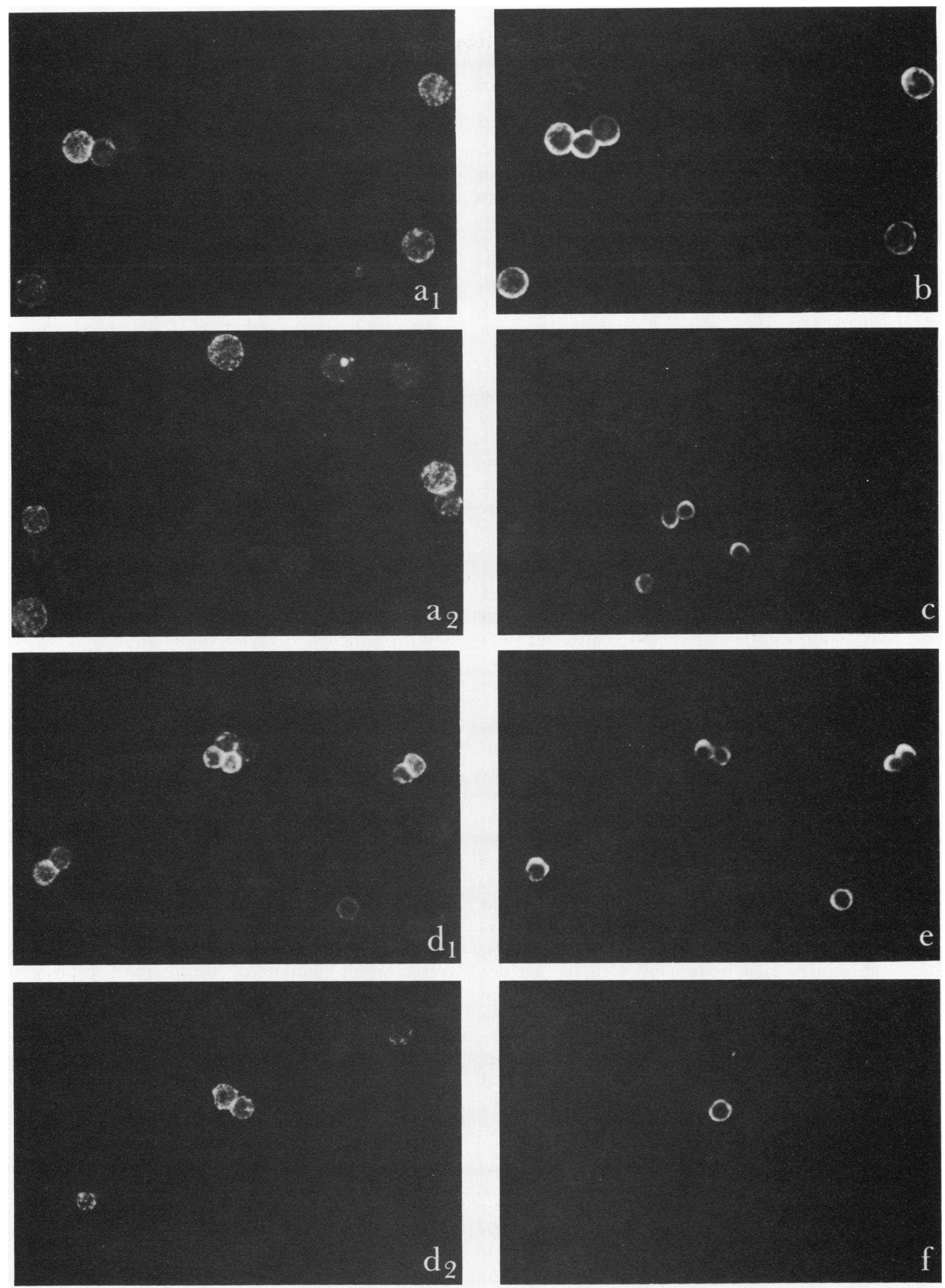
IDDM, especially at the time of diagnosis, and hence to an argument in favor of the autoimmune basis of the disease $(5,15)$. The subsequent reports on the ICAbinding to both $B$ cell and non-B cell cytoplasm and the detection of ICA in nondiabetic subjects questioned, however, the role of ICA in the destruction process of pancreatic B-cells; circulating ICA were therefore considered as a marker for the risk of developing an insulin-dependent state (16-18).

The more recent observation that many newly diagnosed insulin-dependent diabetics present ICSA (8), which provoke a complement-mediated cytotoxicity in vitro $(10,11)$, raises however again the question whether circulating antibodies are actively involved in the pathogenesis of the disease. It seems therefore appropriate to examine whether diabetic ICSA bind specifically to $B$ cells and whether such antibodies also occur in nondiabetic subjects. In the one report which has so far dealt with this question (11), both insulinsynthetizing and somatostatin-synthetizing cells were equally sensitive to the cytotoxic effect of diabetic ICSA, suggesting a lack of specificity. As these studies were performed with cloned islet cells, their extrapolation to the normal situation certainly requires confirmation on normal cell preparations. In the present experiments, ICSA-binding was studied on normal rat islet cells, and its specificity tested by comparing binding with purified $B$ and non-B cells. The islet cells that bind to ICSA were also identified electron microscopically and immunocytochemically.

All sera were first screened for ICSA using unpurified islet cell preparations. Binding of human antibodies to rat islet cell membranes was visualized by a positive rhodamine fluorescent reaction. No fluorescent rings were observed with one group of sera, including most control subjects (ICSA-negative), whereas $30-90 \%$ of the islet cells displayed rhodamine-positive membranes with many diabetic sera (ICSA-positive). For each ICSA-positive serum, a relatively constant percent positive cells was found throughout the experiments; most sera bound to large-sized islet cells, but some sera reacted exclusively with the smaller cells. These results suggest a heterogeneity in the ICSA-positive sera with respect to their affinity for the various islet cell types. Rat B cells are indeed larger than $A$ and $D$ cells, which formed the basis for their purification (12); binding studies with purified B $(>95 \%$ B $)$ and non-B cells $(80 \%$ A, $10 \%$ D, $5 \%$ PP) confirmed the heterogeneity in ICSA and led to the recognition of three classes of ICSA-positive sera, defined on the basis of a binding to $B$ cells (class I), nonB cells (class II), or to both B and non-B cells (class III). It thus became apparent that the variations in the present positive cells in unpurified samples (from 30 to $90 \%$ ) results from interactions with different cell types: in view of the cellular composition of unpurified islet cell preparations $(65 \% \mathrm{~B}, 23 \% \mathrm{~A}, 8 \% \mathrm{D}, 4 \% \mathrm{PP})$, $65 \%$ positive cells can be expected for class I sera, $30 \%$ for class II sera, and $95 \%$ for class III sera, which is consistent with the data.

The present results confirm the higher incidence of ICSA in recent-onset IDDM as compared with normal controls $(8,10,18)$. It should be stressed that this positive correlation was only noted in the age group under $30 \mathrm{yr}$. Although our study was limited to eight newly diagnosed IDDM older than $30 \mathrm{yr}$ it is of interest that only one presented circulating ICSA, which moreover did not bind to rat $B$ cells in vitro. The possibility should be examined whether IDDM developing in older patients is related to autoimmune mechanisms or whether it requires the participation of other immune components. In the group of IDDM younger than $30 \mathrm{yr}$, all ICSA bound to B cells and most of them displayed a selective and strong affinity for B cells. The observation that ICSA from insulin-dependent diabetics are directed specifically towards the B cell, is consistent with a possible active involvement of these antibodies in an autoimmune destruction of the pancreatic $B$ cells and might explain the preferential lysis of B cells, which were exposed in vitro to ICSA from IDDM (19). This view is supported by the absence of such antibodies in 12 patients with autoimmune thyroiditis, although it seems important to repeat this study in "recent-onset autoimmune thyroiditis". It should further be tested whether the weak cell fluorescence, observed with B cell-specific ICSA from NIDD, expresses a history of limited autoimmune agression against the B cells; such process might have decreased the functional B cell mass without provoking immediately diabetes, but with an increased risk to develop the disease in later diabetogenic conditions.

Three diabetic patients (one IDDM older than 30 yr and two NIDDM) presented ICSA that bind exclusively to non-B cells, suggesting the need for further identification of ICSA in each diabetic serum. Since the non-B cell fraction consists of A, D, and PP-cells, studies were undertaken to identify the cell types involved in this binding. An electron microscopical and hormonal analysis of the sorted ICSA-positive cells indicated the presence of $80 \% \mathrm{~A}$ cells and a varying percent $B, D$, and PP cells. Since $>80 \%$ of the sorted cells were rhodamine positive, it was concluded that the ICSA of these patients reacted with a majority to A cells; the sorting technique was however unable to demonstrate binding with other cell types, since the sorted cell fraction contained 5-15\% rhodamine negative cells, which were probably coupled to rhodamine-positive cells and as such deflected into the positive fraction. An additional identification of the ICSApositive cells was therefore attempted via double-label experiments using fluorescein-labeled pancreatic hormone antibodies. These studies indicated that the four 
non-B cell specific sera, identified in three diabetics and one control, reacted with both glucagon and PPcontaining cells. Further studies are now required to examine whether autoimmune reactions exist against $A$ and PP cells and whether they are implicated in islet disease.

\section{ACKNOWLEDGMENTS}

We thank Drs. I. De Leeuw (Universitaire Instelling Antwerpen), M. Devroede, G. Somers, and B. Van Camp (Vrije Universiteit Brussel) for providing the sera, and Dr. E. Maes for his help with the illustrations. We are also grateful to J. C. Hannaert for his skillful technical assistance and to Annemie Kiggen for her excellent secretarial work.

This work was supported by grants from the Belgian Fonds Geneeskundig Wetenschappelijk Onderzoek (3.0021.80 and 20.029) from the Belgian Ministerie Wetenschapsbeleid (80$85 / 9$ ), and from the Nationale Bank van België.

\section{REFERENCES}

1. Gepts, W. 1965. Pathologic anatomy of the pancreas in juvenile diabetes mellitus. Diabetes. 14: 619-633.

2. Nerup, J., O. O. Andersen, G. Bendixen, J. Egeberg, and J. E. Poulsen. 1971. Antipancreatic cellular hypersensitivity in diabetes mellitus. Diabetes. 20: 424-427.

3. Bottazzo, G. F., A. Florin-Christensen, and D. Doniach. 1974. Islet-cell antibodies in diabetes mellitus with autoimmune polyendocrine deficiencies. Lancet. II: 12791282.

4. MacCuish, A. C., J. Jordan, C. J. Campbell, L. J. P. Duncan, and W. J. Irvine. 1974. Cell-mediated immunity to human pancreas in diabetes mellitus. Diabetes. 23: 693697

5. Delprete, G. F., C. Betterle, D. Padovan, G. Erle, A. Toffolo, and G. Bersahi. 1977. Incidence and significance of islet-cell autoantibodies in different types of diabetes mellitus. Diabetes. 26: 909-915.

6. Boitard, C., M. Debray-sachs, A. Pouplard, R. Assan, and J. Hamburger. 1981. Lymphocytes from diabetics suppress insulin release in vitro. Diabetologia. 21: 41-46.

7. Sensi, M., P. Pozzilli, A. N. Gorsuch, G. F. Bottazzo, and A. G. Cudworth. 1981. Increased killer cell activity in insulin dependent (Type I) diabetes mellitus. Diabetologia. 20: 106-109.
8. Lernmark, A., Z. R. Freeman, C. Hofmann, A. H. Rubenstein, D. F. Steiner, R. L. Jackson, R. J. Winter, and H. S. Traisman. 1978. Islet-cell-surface antibodies in juvenile diabetes mellitus. N. Engl. J. Med. 299: 375-380.

9. Kanatsuna, T., A. Lernmark, A. H. Rubenstein, and D. F. Steiner. 1981. Block in insulin release form columnperifused pancreatic B-cells induced by islet cell surface antibodies and complement. Diabetes. 30: 231-234.

10. Dobersen, M. J., J. E. Scharff, F. Ginsberg-Frllner, and A. L. Notkins. 1980. Cytotoxic autoantibodies to beta cells in the serum of patients with insulin-dependent diabetes mellitus. N. Engl. J. Med. 303: 1493-1498.

11. Eisenbarth G. S., M. A. Morris, and R. M. Scearce. 1981 Cytotoxic antibodies to cloned rat islet cells in serum of patients with diabetes mellitus. J. Clin. Invest. 67: 403408.

12. Pipeleers, D. G., and M. A. Pipeleers-Marichal. 1981. A method for the purification of single A, B and D cells for the isolation of coupled cells from isolated rat islets. Diabetologia. 20: 654-663.

13. Herzenberg, L. A., R. G. Sweet, and L. A. Herzenberg 1976. Fluorescence activated cell sorting: a new tool for isolating functional cell types. Sci. Am. 234: 108-117.

14. National Diabetes Group. 1979. Classification and diagnosis of diabetes mellitus and other categories of glucose intolerance. Diabetes. 28: 1039-1057.

15. Irvine, W. J., C. J. McCallum, R. S. Gray, C. J. Campbell L. J. P. Duncan, J. W. Farquhar, H. Vaughan, and P. J. Morris. 1977. Pancreatic islet-cell antibodies in diabetes mellitus correlated with the duration and type of diabetes, coexistent autoimmune disease, and HLA type. Diabetes. 26: 138-147.

16. Bottazzo, G. F., B. M. Dean, A. N. Gorsuch, A. G. Cudworth, and D. Doniach. 1980. Complement-fixing isletcell antibodies in type-I diabetes: possible monitors of active Beta-cell damage. Lancet. I: 668-672.

17. Lernmark, A., B. Hägglof, Z. Freedman, J. Irvine, J. Ludvigsson, and G. Holmgren. 1981. A prospective analysis of antibodies reacting with pancreatic islet cells in insulin-dependent diabetic children. Diabetologia. 20: 471-474.

18. Cahill, G. F., and H. O. Mcdevitt. 1981. Insulin-dependent diabetes mellitus: the initial lesion. N. Engl. J. Med. 304: 1454-1465.

19. Dobersen, M. J., J. E. Scharff, F. Ginsberg-Fellner, and A. L. Notkins. 1981. Preferential lysis of beta cells by islet cell surface antibodies. Diabetologia. 21: 264 (Abstr.). 